Cervera, M. T., V. Storme, A. Soto, B. Ivens, M. Van Montagu, O. P. RAJORA and W. BoERJAN (2005): Intraspecific and interspecific genetic and phylogenetic relationships in the genus Populus based on AFLP markers. Theor Appl Genet 111: 1440-1456.

DaYANANDAN, S., O. P. RAJoRA and K. S. BAwA (1998): Isolation and characterization of microsatellites in trembling aspen (Populus tremuloides) Theor Appl Genet 96: 950-956.

DiFAzIO, S. P. (2002): Measuring and modelling gene flow from hybrid poplar plantations: Implications for transgenic risk assessment. PhD Dissertation, Oregon State University.

Doyle, J. J. and J. L. Doyle (1990): Isolation of Plant DNA from fresh tissue. Focus 12: 13-15.

Hoenicka, H. and M. Fladung (2006): Biosafety in Populus ssp. and other forest trees: from non-native species to taxa derived from traditional breeding and genetic engineering. Trees 20: 131-144.

Jorge, V., A. Dowkiw, P. Faivre-Rampant and C. Bastien (2005): Genetic architecture of qualitative and quantitative Melampsora larici-populina leaf rust resitance in hybrid poplar: genetic mapping and QTL detection. New Physiologist 167: 113-127.

LIU, Z. and G. R. FURNIER (1993): Inheritance and linkage of allozymes and restriction fragment length polymorphisms in trembling aspen. J. Heredity 84: 419-424.

Markussen, T., A. Tusch, B. R. Stephan and M. Fladung (2004): Identification of molecular markers for selected wood properties of Norway Spruce (Picea abies L.[Karst.]) I. Wood density. Silvae Genetica 53: 45-50.
Pena, L. and A. SEguin (2001): Recent advances in the genetic transformation of trees. Trends in Biotechnology 19: $500-506$.

RAHMAN, M. H., S. DAYANANDAN and O. P. RAJORA (2000): Microsatellite DNA markers in Populus tremuloides. Genome 42: 293-297.

Ritter, E., C. Gebhardt and F. SAlamini (1990): Estimation of recombination frequencies and construction of RFLP linkage maps in plants from crosses between heterozygous parents. Genetics 224: 645-654.

RITTER, E. and F. SALAMINI (1996): The calculation of recombination frequencies in crosses of allogamous plant species with application to linkage mapping. Genet. Res. 67: 55-65.

Schreiner, E. J. (1974): Populus L. Poplar. In: SchopMEYER, C. S. (ed). Agriculture Handbook No 450, Forest Service, Seeds of woody plants in the United States. USDA, Washington, DC, pp 645-655.

Strauss, S. H., W. H. Rottmann, A. M. Brunner and L. A. SHEPPARD (1995): Genetic engineering of reproductive sterility in forest trees. Mol Breed 1: 5-26.

Tuskan, G. A., L. E. Gunter, Z. K. Yang, T. M. Yin, M. M. SEwell and S. P. DiFAZIo (2004): Characterization of microsatellites revealed by genomic sequencing of $P$ Populus trichocarpa. Canadian Journal of Forest Research. 34: 85-93.

Yin, T. M., S. P. Difazio, L. E. Gunter, D. RiemenSCHNEIDER and G. A. TUSKAN (2004): Large-scale heterospecific segregation distortion in Populus revealed by a dense genetic map. Theor Appl Genet 109: 451-463.

\title{
Studies on Cytogenetical Variation in Prosopis cineraria (Linn.) Druce - A Key Stone Tree Species of Indian Desert
}

\author{
By D. RAWAT, A. KUMAR and S. R. RAO ${ }^{1)}$ \\ Cytogenetics and Molecular Biology Laboratory, Department of Botany, J. N. Vyas University, \\ Jodhpur- 342005, Rajasthan, India
}

(Received $3^{\text {rd }}$ June 2006)

\begin{abstract}
Prosopis cineraria (Mimosaceae) is an important tree of agro-forestry and ethano- botanical importance with multipurpose utility as wood yielding, fodder, food and medicinal uses. Some remarkable features are observed in the form of phenotypic variation in various populations inhabiting different regions of the Indian desert. To asses these variations male meiotic studies were conducted in ten different accessions collected from four proviences of Rajasthan, India. Analysis of data on chromosome associations, chiasma frequency and their distributions pattern concluded that the somatic chromo-
\end{abstract}

1) Corresponding Author: Telephone \#: +91 - 291-2711227 (R), 919414919943 (M). E-mail: srrao22@yahoo.com some number of $P$. cineraria is $2 \mathrm{n}=2 \mathrm{x}=28$. The complete absence of accessory chromosomes (B) and percentage of pollen stainability indicates an over all genomic stability in $P$. cineraria. Numerical changes like aneuploidy might have played an important role in origin and adoptation of $P$. cineraria against all the odds of the climatic condition of the Indian desert.

Key words: Aneuploidy, Chromosome associations, Chiasma frequency, Genetic variation, Meiosis, Pollen stainability, Prosopis cineraria.

\section{Introduction}

Prosopis cineraria is one of the most common tree of the Indian desert belonging to family Mimosaceae and 
locally known as Khejri. This is a preferred tree for agro-forestry and is a popular renewable source of fuel, fodder, timber and vegetables needed by local populace (BHANDARI, 1990). It is an important component of Indian desert ecosystem as biomass producer and it enriches desert soil, fixes atmospheric nitrogen and provides a green coverage (FELKER and BANDURSKI, 1979; FELKER, 1979, 1981; LEAKY and LAST, 1980; BASAK and GOYAL, 1975, 1980; IsELY, 1982). The immature and mature pods are edible, energy rich and have high nutritional value (GuPTA et al., 1974). P. cineraria is well adopted to arid and semi arid conditions of the Indian desert, perhaps due to their well developed and expansive tap root system which reach up to a length of $20 \mathrm{~m}$ in length, often reaching the ground water resources (FELKER and BANDURSKI, 1979). In Rajasthan there is a common practice to harvest the green pods, which are boiled, dried and sold as vegetable either singly or in combination with other local plant products to yield Pach-kutta, a mixture of five species. Green pods, locally called as sangri or hangri, and the ripened ones, as termed as khokha, are used as vegetables. During India's infamous Rajputana famine (1868-69) many lives were spared using the sweetish bark as a food. It was ground into flour to make cakes. Wood used for boat frames, houses, posts, and tool handles. The poor form of unimproved trees limits use of as timber, With $31 \%$ soluble potassium salts, the wood ash may serve as a potash source. Pods and lopping provide valuable fodder during the dry season. Bark and leaf galls are often used for tanning. The gum exuding from the trunk is suggestive of gum Arabic (DukE, 1983). Reported to be astringent, demulcent, and pectoral, ghaf is a folk remedy for various ailments. The flowers are mixed with sugar and administered to prevent miscarriage. The ashes are rubbed over the skin to remove hair. The bark considered antihelminthic, refrigerant, and tonic that is used for asthma, bronchitis, dysentery, leucoderma, leprosy, muscle tumors, piles, and wandering of the mind. Smoke from the leaves is used for eye troubles, but the fruit is said to be indigestible, inducing biliousness, destroying nails and hairs. Due to multifacet utility mentioned above, the pressure for its diverse products is mounting alarmingly and therefore there is an urgent need for thorough exploration and exploitation of all the available genetic variation in $P$. cineraria. Therefore the present investigation has been undertaken with the main objective of understanding the genetic diversity using cytological parameters. From the quick perusal of earlier published literature, it is amply clear that $P$. cineraria did not receive much attention of either cytologists and/or cytogeneticists and very scant information is available on this species. Only a single study on cytological aspects of $P$. cineraria by SHEKHAWAT et al. (1993) is available which reports the chromosome number of this species as $2 n=28$ through the analysis of in vitro regenerants. Therefore an attempt has been made to carry out genomic analysis using cytological parameters in various populations of $P$. cineraria, collected from different areas of Rajasthan. The present investigation on meiotic details is an effort to document valuable information on chromosome number, their associations/ disjunctional pattern besides recording remarkable variations. Such studies will help in assessing the range and quantum of genetic diversity existing among the natural populations of $P$. cineraria (STACE, 2000).

\section{Material and Methods}

To locate the populations of Prosopis cineraria field trips were conducted in four provinces Jodhpur, Barmer, Jaisalmer and Nagaur of Rajasthan state (Table 1) where maximum diversity is observed. The specimens of all the selected trees were deposited with herbarium Department of Botany J. N. V. University Jodhpur and accession numbers were obtained (Table 1). Flower buds of appropriate size for meiotic studies were collected from selected mature trees and fixed in freshly prepared carnoy's fluid for a minimum of 24 hours at room temperature and latter stored in $70 \%$ alcohol at $100^{\circ} \mathrm{C}$.

Anthers were squashed in $1 \%$ aceto-carmine solution for meiotic studies. On average 25 Pollen Mother Cells (PMCs) were analyzed at diplotene/diakinesis/ metaphase I to estimate the range of chromosome asso-

Table 1. - Place of collection, mean number and range of associations at diplotene/diakinesis/metaphase I in Prosopis cineraria accessions.

\begin{tabular}{|c|c|c|c|c|c|c|c|c|c|c|c|c|c|c|c|c|c|}
\hline \multirow{4}{*}{$\begin{array}{l}\text { Accession } \\
\text { Number }\end{array}$} & \multirow{4}{*}{$\begin{array}{l}\text { Place of } \\
\text { collection } \\
\text { (District) }\end{array}$} & \multirow{4}{*}{$\begin{array}{l}\text { No of } \\
\text { Cells } \\
\text { analyzed }\end{array}$} & \multirow{3}{*}{\multicolumn{2}{|c|}{$\begin{array}{l}\text { Cells with } \\
\mathrm{n}=14\end{array}$}} & \multicolumn{11}{|c|}{ Chromosome Associations } & \multirow{3}{*}{\multicolumn{2}{|c|}{ Univalents }} \\
\hline & & & & & \multirow{2}{*}{\multicolumn{3}{|c|}{ Quadrivalents }} & \multicolumn{8}{|c|}{ Bivalents } & & \\
\hline & & & & & & & & \multicolumn{3}{|c|}{ Total } & \multicolumn{3}{|c|}{ Ring } & \multicolumn{2}{|r|}{ Rod } & & \\
\hline & & & $\mathrm{No}$ & $\%$ & No & Mean $\mathrm{F}$ & Range & No & Mean 1 & Range & No & Mean & Range & No & Mean $\quad$ Range & No & Mean Range \\
\hline JNVU/RI/2005/1 & $\begin{array}{c}\text { Devikot } \\
\text { (Jaisalmer) }\end{array}$ & 30 & 28 & 93.33 & - & - & - & 418 & $13.93 \pm 0.24$ & 13-14 & 412 & $13.73 \pm 0.67$ & $11-14$ & 6.00 & $0.20 \pm 0.54 \quad 0-2$ & 4.00 & $0.13 \pm 0.49 \quad 0-2$ \\
\hline JNVU/R/2005/2 & $\begin{array}{l}\text { Pokharn } \\
\text { (Jaisalmer) }\end{array}$ & 39 & 38 & 97.43 & - & - & - & 545 & $14.00 \pm 0.00$ & $13-14$ & 524 & $13.40 \pm 0.89$ & $11-14$ & 21.00 & $0.53 \pm 0.87$ & 2.00 & $0.05 \pm 0.31 \quad 0-2$ \\
\hline JNVU/RI/2005/3 & $\begin{array}{c}\text { Pachpadra } \\
\text { (Barmer) }\end{array}$ & 25 & 22 & 88.00 & - & - & - & 346 & $13.84 \pm 0.36$ & $13-14$ & 346 & $13.84 \pm 0.36$ & 13-14 & 0.00 & $0.00 \pm 0.00 \quad 0-0$ & 6.00 & $0.24 \pm 0.64 \quad 0-2$ \\
\hline JNVU/RI/2005/4 & $\begin{array}{l}\text { Balotra } \\
\text { (Barmer) }\end{array}$ & 24 & 18 & 75.00 & 1.0 & $04 \pm 0.19$ & $\begin{array}{ll}9 & 0-1\end{array}$ & 327 & $13.62 \pm 0.69$ & $12-14$ & 317 & $13.20 \pm 0.99$ & $10-14$ & 10.00 & $0.41 \pm 0.70 \quad 0-2$ & 14.00 & $0.58 \pm 1.22 \quad 0-4$ \\
\hline JNVU/RI/2005/5 & $\begin{array}{l}\text { Nakoda } \\
\text { (Barmer) }\end{array}$ & 25 & 25 & 100.00 & - & - & - & 350 & $14.00 \pm 0.00$ & 14-14 & 323 & $12.92 \pm 0.93$ & $11-14$ & 27.00 & $1.08 \pm 0.93 \quad 0-3$ & 0.00 & $0.00 \pm 0.00 \quad 0-0$ \\
\hline JNVU/RI/2005/6 & $\begin{array}{c}\text { Ren } \\
\text { (Nagaur) }\end{array}$ & 26 & 13 & 50.00 & - & - & - & & $13.30 \pm 0.78$ & $11-14$ & 337 & $12.96 \pm 1.05$ & $11-14$ & 10.00 & $0.38 \pm 0.68 \quad 0-2$ & 34.00 & $1.30 \pm 5.26 \quad 0-6$ \\
\hline JNVU/RI/2005/7 & $\begin{array}{c}\text { Jayal } \\
\text { (Nagaur) }\end{array}$ & 27 & 18 & 66.66 & - & - & - & 367 & $13.59 \pm 0.62$ & $12-14$ & 362 & $13.40 \pm 0.73$ & $12-14$ & 5.00 & $0.18 \pm 0.54 \quad 0-2$ & 23.00 & $0.85 \pm 1.25 \quad 0-4$ \\
\hline JNVU/RI/2005/8 & $\begin{array}{c}\text { Kejherli } \\
\text { (Jodhpur) }\end{array}$ & 24 & 19 & 79.16 & - & - & - & 331 & $13.79 \pm 0.40$ & 13-14 & 328 & $13.66 \pm 0.66$ & $11-14$ & 3.00 & $10.12 \pm 0.43 \quad 0-2$ & 10.00 & $0.41 \pm 0.81 \quad 0-2$ \\
\hline JNVU/R/2005/9 & $\begin{array}{c}\text { Gudda } \\
\text { (Jodhpur) }\end{array}$ & 25 & & 100.00 & - & - & - & 350 & $14.00 \pm 0.00$ & $14-14$ & 322 & $12.80 \pm 1.21$ & $10-14$ & 28.00 & $0.12 \pm 1.21 \quad 0-4$ & 0.00 & $0.00 \pm 0.00 \quad 0-0$ \\
\hline JNVU/RI/2005/10 & $\begin{array}{l}\text { Kailana } \\
\text { (Jodhpur) }\end{array}$ & 24 & & 100.00 & - & - & - & 336 & $14.00 \pm 0.00$ & $14-14$ & 316 & $13.16 \pm 0.79$ & $11-14$ & 20.00 & $0.83 \pm 0.79 \quad 0-3$ & 0.00 & $0.00 \pm 0.00 \quad 0-0$ \\
\hline
\end{tabular}


ciations and recombinational frequencies through chiasma analysis. At anaphase I/II 15-20 cells were analyzed for distributional pattern of chromosomes. To estimate the quantum of viable male gametes, pollen grains were stained in 1:1 glycerine: aceto-carmine mixture considering the stained pollen as viable ones. Agfa Copex Pan photonegative film (ASA-20) was used to make photomicrographs from temporary preparations.

\section{Results}

The details regarding various accessions analyzed in the present investigations, their place of collection, total number of PMCs analyzed and their associations at diplotene/diakinesis/metaphase I are summarized in Table 1. The data on total and mean number of chiasmata and its range along with number of chiasmata terminalized, terminalization coefficient and its percentage pollen stainability is summarized in Table 2. The distribution pattern of chromosomes at anaphase I have been detailed in Table 3. Most of these observations are illustrated in Figs. 1-30.

From the data summarized in Table 1, it is amply clear that all the accessions presently investigated were characteristic in showing 14 bivalents at diplotene/ diakinesis/metaphase I in all the PMCs analyzed. Only one quadrivalent was encountered in one accession (JNVU RI/2005/4) collected from Balotra (Barmer district). The mean value of total number of bivalents per PMC was observed to be highest (14.00) in four (JNVU RI/2005/2, JNVU RI/2005/5, JNVU RI/2005/9, and JNVU RI/2005/10) and lowest (13.30) in one accession (JNVU RI/2005/6) respectively.

Among the bivalents, ring types were encountered more frequently than rod types. The mean value for ring

Table 2. - Mean number, range of chiasmata, terminalization coefficient and percentage pollen stainability in Prosopis cineraria accessions.

\begin{tabular}{|c|c|c|c|c|c|c|c|}
\hline \multirow{2}{*}{$\begin{array}{c}\text { Accession } \\
\text { Number }\end{array}$} & $\begin{array}{c}\text { No. of } \\
\text { cells } \\
\text { analyzed }\end{array}$ & Mean & Range & Terminalized & Unterminalized & $\begin{array}{c}\text { Terminalization } \\
\text { coefficient }\end{array}$ & $\begin{array}{l}\text { Percentage } \\
\text { Pollen } \\
\text { Stainability }\end{array}$ \\
\cline { 5 - 8 } & 30 & $27.60 \pm 0.86$ & $24-28$ & $26.20 \pm 1.59$ & $1.43 \pm 1.33$ & 0.94 & 90.12 \\
\hline JNVU/ RI/2005/1 & 39 & $27.35 \pm 1.02$ & $25-28$ & $26.02 \pm 2.32$ & $1.35 \pm 1.64$ & 0.90 & 89.31 \\
\hline JNVU/ RI/2005/2 & 25 & $27.60 \pm 0.74$ & $26-28$ & $25.56 \pm 2.15$ & $2.16 \pm 2.09$ & 0.92 & 80.45 \\
\hline JNVU/ RI/2005/4 & 24 & $27.00 \pm 1.22$ & $24-28$ & $22.80 \pm 3.92$ & $4.58 \pm 3.74$ & 0.84 & 87.67 \\
\hline JNVU/ RI/2005/5 & 25 & $26.80 \pm 1.03$ & $26-28$ & $25.30 \pm 2.02$ & $1.52 \pm 1.41$ & 0.94 & 90.72 \\
\hline JNVU/ RI/2005/6 & 26 & $26.30 \pm 1.72$ & $22-28$ & $23.23 \pm 3.42$ & $3.07 \pm 3.06$ & 0.88 & 90.35 \\
\hline JNVU/ RI/2005/7 & 27 & $27.00 \pm 1.27$ & $24-28$ & $24.37 \pm 3.24$ & $2.62 \pm 3.09$ & 0.90 & 91.45 \\
\hline JNVU/ RI/2005/8 & 24 & $27.45 \pm 1.02$ & $24-28$ & $21.12 \pm 4.32$ & $5.04 \pm 4.08$ & 0.81 & 92.66 \\
\hline JNVU/ RI/2005/9 & 25 & $26.80 \pm 1.21$ & $24-28$ & $24.16 \pm 2.75$ & $2.72 \pm 2.97$ & 0.89 & 89.72 \\
\hline JNVU/ RI/2005/10 & 24 & $27.04 \pm 0.88$ & $25-28$ & $25.50 \pm 1.47$ & $1.54 \pm 1.25$ & 0.94 & 90.38 \\
\hline
\end{tabular}

Table 3. - Anaphase I distribution in Prosopis cineraria accessions.

\begin{tabular}{|c|c|c|c|c|c|}
\hline $\begin{array}{c}\text { Accession } \\
\text { number }\end{array}$ & $2 \mathrm{n}$ & $\begin{array}{c}\text { Number of } \\
\text { cells } \\
\text { analyzed }\end{array}$ & $\begin{array}{c}\text { Chromosome } \\
\text { distribution }\end{array}$ & $\begin{array}{c}\text { No. of } \\
\text { cells }\end{array}$ & Percentage \\
\hline JNVU/ RI/2005/1 & 28 & 20 & $14: 14$ & 20 & 100.00 \\
\hline JNVU/ RI/2005/2 & 28 & 20 & $14: 14$ & 19 & 95.00 \\
$14: 1 \mathrm{U}: 13$ & 1 & 5.00 \\
\hline JNVU/ RI/2005/3 & 28 & 15 & $14: 14$ & 15 & 100.00 \\
\hline JNVU/ RI/2005/4 & 28 & 20 & $14: 14$ & 19 & 95.00 \\
& & 15 & $14: 14$ & 15 & 100.00 \\
\hline JNVU/ RI/2005/5 & 28 & 15 & $14: 14$ & 13 & 86.66 \\
\hline JNVU/ RI/2005/6 & 28 & 15 & $13: 2 \mathrm{U}: 13$ & 02 & 13.34 \\
\hline JNVU/ RI/2005/7 & 28 & 15 & $14: 14$ & 15 & 100.00 \\
\hline JNVU/ RI/2005/8 & 28 & 20 & $14: 14$ & 20 & 100.00 \\
\hline JNVU/ RI/2005/9 & 28 & 20 & $14: 14$ & 20 & 100.00 \\
\hline JNVU/RI/2005/10 & 28 & 15 & $14: 14$ & 14 & 93.33 \\
& & & $13: 1 \mathrm{~B}: 13$ & 1 & 6.67 \\
\hline
\end{tabular}

$\mathrm{U}=$ Univalents, $\mathrm{B}=$ Bivalents. 


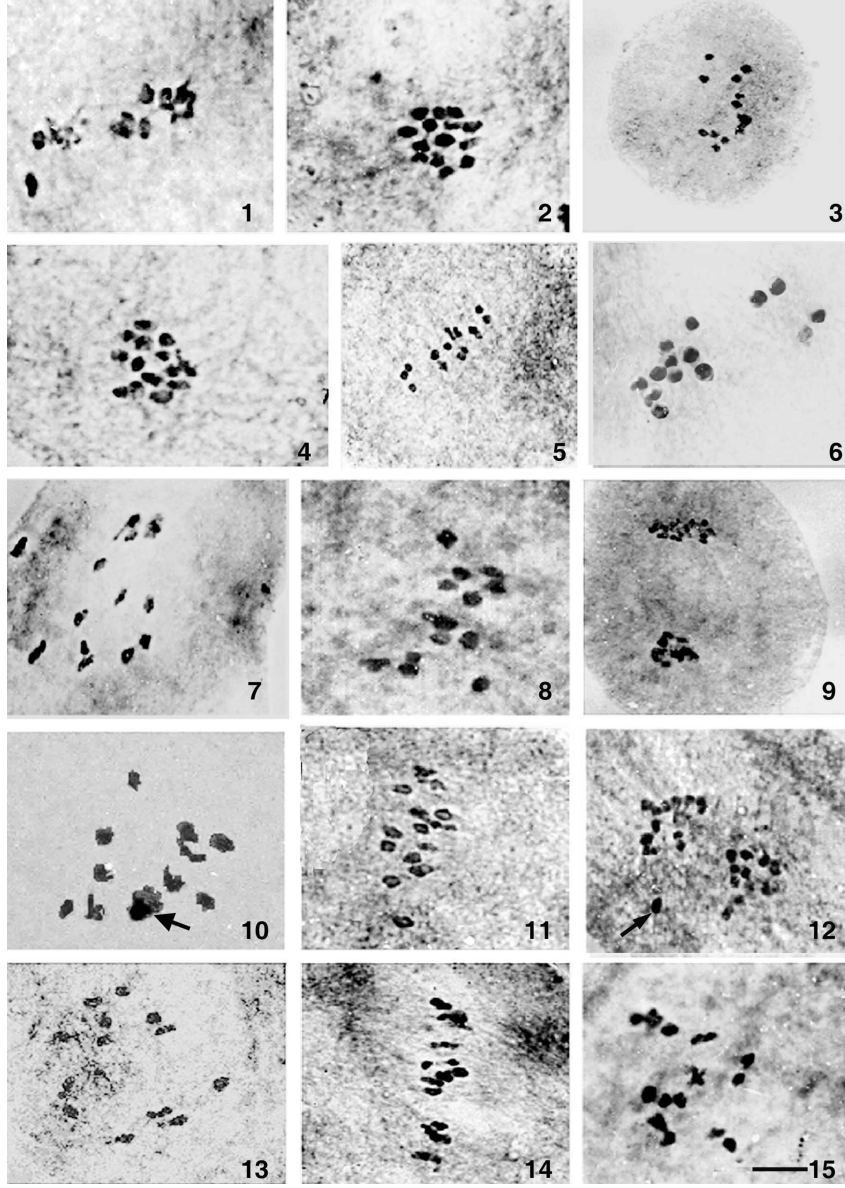

Figure 1. - Male meiosis in Prosopis cineraria accessions; (1-3) $P$. cineraria JNVU/RI/2005/1, 1. Diakinesis 14II. 2-3. Metaphase I 14II. (4-6) P. cineraria JNVU/RI/2005/2, 4. Diakinesis 14II. 5-6. Metaphase I 14II. (7-9) $P$. cineraria JNVU/RI/2005/3, 7. Diakinesis 14II. 8. Metaphase I 14II. 9. Anaphase I 14II. (10-12) P. cineraria JNVU/RI/2005/4 10. Diakinesis 1IV + 12II. 11. Metaphase I 14II. 12. Anaphase I (Laggard). (13-15) P. cineraria JNVU/RI/2005/5, 13. Diakinesis 14II. 14-15. Metaphase I 14II. Scale bar $=10 \mu \mathrm{m}$. (Arrow showing quadrivalent and laggard).

types ranged between 12.80 (JNVU RI/2005/9) and 13.84 (JNVU RI/2005/3) while rod bivalents, though their number was lower than expected, were encountered in all accessions except J.N.V.U. RI/2005/3 were they were altogether absent. In three accessions viz. JNVU RI/2005/5, JNVU RI/2005/9 and JNVU $\mathrm{RI} / 2005 / 10$ no univalents were encountered, while in all other accessions univalents were characteristically present, with the highest number of 6 univalents per PMC was recorded in JNVU RI/2005/6.

From the data presented in Table 2 it is apparent that mean number of chiasmata per cell ranged from 26.30 JNVU RI/2005/6 to 27.80 as observed in two accessions viz. JNVU RI/2005/9, while the other accessions had the values ranging between the two extremes. A minimum of 22 (JNVU RI/2005/6) and a maximum number of 28 chiasmata were found in all the accessions. JNVU $\mathrm{RI} / 2005 / 8$ was characteristic in having minimum number of terminalized chiasmata per PMC (21.12) while a maximum of 26.20 was recorded in JNVU RI/2005/1. Similarly JNVU RI/2005/2 had minimum number of un-
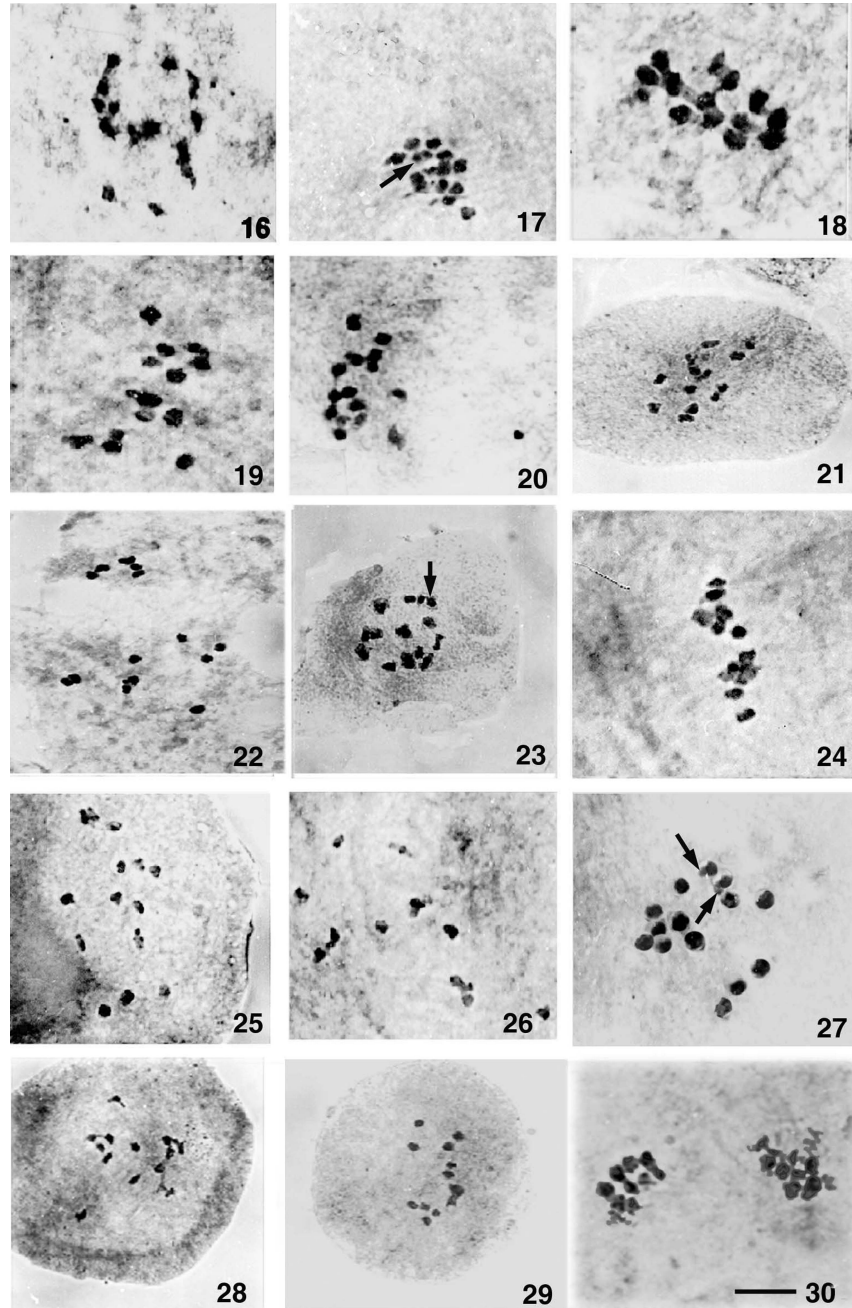

Figure 2. - Male meiosis in Prosopis cineraria accessions; (16-18) P. cineraria JNVU/RI/2005/6, 16. Diakinesis 14II. 17. Diakinesis 13II + 2I. 18. Metaphase I 14II. (19-21) P. cineraria JNVU/RI/2005/7, 19-21. Metaphase I 14II. (22-24) P. cineraria JNVU/RI/2005/8, 22. Diakinesis 14II. 23. Diakinesis 13II + 2I. 24. Metaphase 14II. (25-27) P. cineraria JNVU/RI/2005/9, 25-26. Diakinesis 14II. 27. Metaphase I 13II + 2I. (28-30) P. cineraria JNVU/RI/2005/10, 28. Diakinesis 14II. 29. Metaphase I 14II. 30. Anaphase I. Scale bar $=10 \mu \mathrm{m}$. (Arrow showing univalents).

terminalized chiasmata whereas JNVU RI/2005/8 had recorded highest value of 5.04 . The terminalization coefficient mostly ranged between 0.81 to 0.94 in all accessions.

Majority of the PMCs analyzed at anaphase I/II had shown equal distribution of chromosomes (14:14) in all the accessions presently investigated. Few PMCs in JNVU/RI/2005/2, JNVU/RI/2005/6 and JNVU/RI/2005/10 had lagging bivalents (0-1) and /or lagging univalents (1-2) respectively (Table 1). The percentage pollen stainability ranged between 80.45 (JNVU/RI/2005/2) to 92.66 (JNVU/RI/2005/8) among various accessions of $\mathrm{P}$. cineraria presently studied.

When the meiotic data collected from ten different accessions belonging to four different locations were compared it was observed that barring three accessions, one from Barmer ((JNVU/RI/2005/5) and two from Jodhpur (JNVU/RI/2005/9) (JNVU/RI/2005/10), all the other 
accessions had shown both mixture of bivalents and univalents. Rarely multivalent were encountered only one quadrivalent was observed in the accession from Balotra when chromosome associations were analyzed from different locations. There were no marked variations between plants collected from four locations with respect to total number of bivalents; however significant differences were found in proportion of ring and rod types as observed in JNVU/RI/2005/5 collected from Barmer where no rod type bivalents were observed. Variations were observed in total number of univalents in PMCs from different locations. One accession from Barmer (JNVU/RI/2005/5) and two from Jodhpur (JNVU/RI/2005/9, JNVU/RI/2005/10) are unique not encountered. The highest number of univalents was observed in the PMCs of plants collected from Nagaur location.

When the data for mean number of chiasmata per PMC was compared from different locations, not many variations were observed. The terminalization coefficient was observed to be almost same for the accessions collected from different locations hovering around 0.90 approximately. From the studies on percentage pollen stainability it is clear that no significant variability exhibited in the plants collected from four different locations.

Analysis of distribution of chromosome, at anaphase I had shown that the ten accessions presently studied except three accessions, had shown equal distribution. The three accessions (JNVU/RI/2005/2, JNVU/RI/ 2005/6, JNVU/RI/2005210) were characteristics in having abnormalities in the form of laggards (Univalents/Bivalents) in at least few PMCs.

\section{Discussion}

The oldest name for Khejri is Mimosa cineraria Linn. and later Linnaeus himself treated this taxon under the genus Prosopis and called it Prosopis spicigera Linn. Mant. But as per the Code of Botanical Nomenclature, MACBRIDE (1919) validated the above combination under the genus Prosopis and species cineraria and thus the correct name is Prosopis cineraria (Linn.). In some translations of the Indian scripture by European Sanskrit scholars i.e. MoniER-Williams (1899), this tree has been described as Mimosa suma or Acacia suma while its Sanskrit name is Sami (MANn and SexenA, 1980).

$P$. cineraria has been investigated cytologically by SHEKHAWAT et al. in 1993 during the analysis of in vitro regenerants. The chromosome counts for this species was reported by them as $2 \mathrm{n}=28$. However, the chromosome counts of natural populations are being reported for the first time. The gametic chromosome number is reported as $2 n=28$. From our investigations combined with earlier reports, it is amply clear the somatic chromosome number of $P$. cineraria and its related species were characterized by the $2 \mathrm{n}$ numbers of $22,26,28,52$, and 56,112 . From the close analysis of these observations it is apparent that these are at least two series of polyploid, based evolution adopted by the genus Prosopis with basic number of $\mathrm{x}=13$ and $\mathrm{x}=14$. The first polyploid series based on $\mathrm{x}=13$ might have given rise to species like $P$. glandulosa $2 \mathrm{n}=26$ RAMANATHAN (1950) and $P$. juliflora cytotypes $2 \mathrm{n}=52$ (SAMPATH and RAMANATHAN, 1949). Similarly the other line of evolution based on $\mathrm{x}=14$ might have given rise to species like $P$. cineraria $(2 \mathrm{n}=28$; present author $), P$. juliflora cytotypes $2 \mathrm{n}=56$ SAREEN et al. (1974) and $P$. juliflora cytotypes $2 \mathrm{n}=112$ HuNZIKER et al. (1975). However $2 \mathrm{n}=22$ P. juliflora (MEHRA, 1940) was found as a deviant somatic chromosome counts in this series. This deviation may be due to the irregularities occur in distribution of chromosome at anaphase I/II.

All the accessions investigated presently were found to exhibit expected number of 14 bivalents per PMCs at prophase I metaphase. However, a few PMCs with a combination of both bivalents and univalents were also encountered. Only single accession i.e. P. cineraria JNVU/RI/2005/4 was found to have chromosome association in the form of quadrivalent in one PMC, which consequently did not reflect in any abnormal behavior of chromosomes. Further, a few PMCs were observed to have univalents, whose number ranged from $0-6$ in different accessions. These observations are the direct indicative of partial homozygosity among bivalents. On contrary, the rod bivalents were found to be completely absent in $P$. cineraria JNVU/RI/2005/3 and a maximum of four were found in few PMCs in the remaining accessions. These observations support our view that genetic recombinations are restricted only to the distal regions of bivalents vis-a-vis randomized recombinations. The highest mean value for chiasma frequency was observed in two accessions $P$. cineraria JNVU/RI/2005/1 and $P$. cineraria JNVU/RI/2005/3 whereas the lowest in $P$. cineraria JNVU/RI/2005/5 and $P$. cineraria JNVU/RI/ $2005 / 9$. The remaining accessions had values ranging between these two. Two chiasma per bivalent was the common observation while rod bivalents had just one chiasma, which is mostly found terminalized. Although extreme small size of chromosomes, a common feature of arid zone tree species KUMAR and RAO (2002, 2003); KUMAR et al. (2002), has hindered the exact location of chiasma, however, it is mostly observed that the chiasma are distal in position, thereby localizing genetic recombination only in distal regions. It is a phenomenon, which is reported in a large number of plants including several leguminous crops and arid zone tree species (SYBENGA, 1972; Singh, 1993; VERMA, 1981; Kesavacharyulu, 1988; Kumar and RAO, 2002, 2003). The average number of terminalized chiasmata per PMC ranged between 21.12 (JNVU/RI/2005/8) to 26.20 (JNVU/RI/2005/1) giving the terminalization coefficient a minimum value of $0.81(\mathrm{JNVU} / \mathrm{RI} / 2005 / 8)$ and a maximum of 0.94 (JNVU/RI/2005/1, JNVU/RI/2005/5 and JNVU/RI/2005/10). The terminalization coefficient of other accessions ranged between these two extremes.

The chromosome distribution was observed as normal in the PMCs analysed at anaphase I and II in all the accessions. In $5-13 \%$ cells of $P$. cineraria JNVU/RI/ 2005/2 and $P$. cineraria JNVU/RI/2005/6 had one to two univalents in the form of laggards. However single accession $P$. cineraria JNVU/RI/2005/10 was found to have lagging bivalents. This information reflects the 
abnormal disjunction of chromatids /chromosomes at anaphase I and II in fewer PMCs. The percentage pollen stainability ranged between 80.45 and 92.66 , which was observed in JNVU/RI/2005/3 and JNVU/RI/2005/8 respectively. It is apparent from the present investigation that due to similar cytological observations of all the accessions, the morphological variation could not be directly correlated to cytological variation. As this leguminous tree grows well against all the odds of the climatic conditions, abnormalities are expected in genome structure and organization owing to environmental factors. To investigate the genomic variations at intraspecific level it is recommended to initiate investigations that are expected to reveal the exact mode of genesis, nature and quantity of variation.

\section{Acknowledgements}

The present work was supported by a grant sanctioned to AK under DST-SERC Fast Track Scheme (SR/FT/L29/2003) from the Department of Science and Technology, Government of India, New Delhi. We are thankful to Dr. A. BoHra, Head, Department of Botany, J. N. VYAS University, Jodhpur for providing facilities. Help rendered by Ms. SANGEETA is thankfully acknowledged.

\section{References}

BASAK, M. K. and S. K. GoYAL (1980): Studies on the biology of tree legumes-Rizobium symbiosis: Nodulation pattern and cross inoculation trails with tree legumes and cultivated legumes. Annals of Arid Zone 19: 427-431.

BASAK, M. K. and S. K. GoYAL (1982): Studies on tree legumes II. Further edition to the list of nodulating tree legumes. Plant and Soil 56: 33-37.

BHANDARI, M. M. (1990): Flora of Indian Desert. M.P.S. Reports, Jodhpur, India.

FELKER, P. (1979): Mesquite: An all purpose leguminous arid land tree. In: RITCHIE, G. A. (Ed). New Agricultural Crops, AAAS selected symposium. West view Press, Boulder, Colorado, USA. Pp 38.

FELKER, P. (1981): Uses of tree legumes in semi arid regions. Economic Botany 35: 176-186.

FELKER, P. and R. S. BANDURSKI (1979): Uses and potential of Leguminous trees for minimal energy input. Agriculture Economic Botany 33: 172-184.

Gupta, M. L., B. M. GANDHI and B. N. TANDON (1974): An unconventional legume - Prosopis cineraria. The American Journal of clinical Nutrition 27: 1035-1036.

Hunziker, J. H., L. Poggio, C. A. Naranjo, R. A. Palaeios and A. B. ANDRADA (1975): Cytogenetics of some species and natural hybrid in Prosopis (Leguminaceae). Canadian Journal Genetics and Cytology 53: 253-262.

ISELY, D. (1982): Leguminosae and Homosapiens. Economic Botany 36: 46-70.

Duke, A. J. (1983): Handbook of Energy crops (Unpublished).
Kesavacharyulu, K. (1988): Cytogenetics of Vicia. Ph. D. Thesis, University of Jodhpur, Jodhpur (India).

KUMAR, A. and S. R. RAO (2002): Cytological investigations in some important tree species of Rajasthan II. Male meiosis in the genus Anogeissus (DC.) Guill., and A. Rich. Caryologia 55: 63-72.

Kumar, A. and S. R. RAO and T. S. RAthore (2002): Cytological investigation in some important tree species of Rajasthan IV. Male meiosis studies in the genus Salvadora L. Cytologia 67: 105-115.

Kumar, A., S. R. RAO and N. S. SheKhaWAT (2003): Cytological investigations in some important tree species of Rajasthan VI. Radiation induced chromosome aberrations in Anogeissus pendula and A. latifolia. Journal of Cell and Molecular Biology 2: 105-111.

LEAKY, R. R. B and F. T. LAST (1980): Biology and potential of Prosopis species in aria environments, with particular to P. cineraria. Journal of Arid Environment 3: 9-24.

MACBRIDE (1919): Taxonomy, morphology, growth and reproduction of Khejri and its succession in north-west India. In: MANN, H. S. and SAXENA, S. K. (Eds.). Khejri (Prosopis cineraria) In the Indian Desert- its role in agroforestry. Central Arid Zone Research Institute, Jodhpur. India. Monograph 11: 5-15.

MANn, H. S. and S. K. SAXENA (1980): KHEJRI (Prosopis cineraria) in the Indian desert its role in Agroforestry. Central arid zone research institute, Jodhpur.

MenrA, B. (1940): Development of gametophytes in Prosopis juliflora. Proc. $27^{\text {th }}$ Indian. Science Congress Part 3: 133.

Monier-Willams, M. (1899): Sanskrit- English Dictionary. Munshi Ram Manhor Lal Publisher Pvt. Ltd., New Delhi. Pp 1054.

RAMANATHAN, K. (1950): Addendum to list of chromosome number in Economic Plant. Current Science 19: 155.

SAMPATH, S. and K. RAMANATHAN (1949): Chromosome number in Indian Economic Plants II Current Science 18: 408-409.

SAMPATH, S. and K. Ramanathan (1949): Chromosome number in Indian Economic Plants II. Current Science 18: 408-409.

Sareen, T. S., S. Kant and R. Pratap (1974): IN IOPB chromosome reports XLV Taxon 23: 619-624.

Shekhawat, N. S., T. S. Rathore, R. P. Singh, N. S. Deora and S. R. RAO (1993): Factors affecting in-vitro clonal propogation in Prosopis cineraria. Plants growth Regulation 12: 273-280.

Singh, R. J. (1993): Plant Cytogenetics. CRC press, Inc. Boca Raton. Florida. USA.

Stace, C. A. (2000): Cytology and cytogenetics as a fundamental taxonomic resource for the $20^{\text {th }}$ and $21^{\text {st }}$ centuries. Taxon 49: 451-477.

SybenGA, J. (1972): General cytogenetics. North-Holland publication company, Amsterdam.

VERMA, R. C. (1981): Cytogenetics of Crotolaria and Phlox. Ph.D. Thesis, University of Jodhpur, Jodhpur. 